\title{
Kinetic effect of heating rate on the thermal maturity of carbonaceous material as an indicator of frictional heat during earthquakes
}

\author{
Shunya Kaneki $i^{*}$ and Tetsuro Hirono
}

\begin{abstract}
Because the maximum temperature reached in the slip zone is significant information for understanding slip behaviors during an earthquake, the maturity of carbonaceous material (CM) is widely used as a proxy for detecting frictional heat recorded by fault rocks. The degree of maturation of $\mathrm{CM}$ is controlled not only by maximum temperature but also by the heating rate. Nevertheless, maximum slip zone temperature has been estimated previously by comparing the maturity of $\mathrm{CM}$ in natural fault rocks with that of synthetic products heated at rates of about $1{ }^{\circ} \mathrm{Cs}^{-1}$, even though this rate is much lower than the actual heating rate during an earthquake. In this study, we investigated the kinetic effect of the heating rate on the $\mathrm{CM}$ maturation process by performing organochemical analyses of $\mathrm{CM}$ heated at slow $\left(1{ }^{\circ} \mathrm{C} \mathrm{s}^{-1}\right)$ and fast $\left(100^{\circ} \mathrm{C} \mathrm{s}^{-1}\right)$ rates. The results clearly showed that a higher heating rate can inhibit the maturation reactions of $\mathrm{CM}$; for example, extinction of aliphatic hydrocarbon chains occurred at $600^{\circ} \mathrm{C}$ at a heating rate of $1{ }^{\circ} \mathrm{C} \mathrm{s}^{-1}$ and at $900^{\circ} \mathrm{C}$ at a heating rate of $100^{\circ} \mathrm{C} \mathrm{s}^{-1}$. However, shear-enhanced mechanochemical effects can also promote $\mathrm{CM}$ maturation reactions and may offset the effect of a high heating rate. We should thus consider simultaneously the effects of both heating rate and mechanochemistry on CM maturation to establish CM as a more rigorous proxy for frictional heat recorded by fault rocks and for estimating slip behaviors during earthquake.
\end{abstract}

Keywords: Carbonaceous material, IR spectrometry, Raman spectrometry, Pyrolysis, Frictional heat, Heating rate

\section{Introduction}

Frictional heat generated in fault zones constitutes the largest part of the total seismic energy budget during an earthquake (e.g., Chester et al. 2005), and it triggers several kinds of fault-weakening mechanisms, including thermal pressurization (Sibson 1973) and melt lubrication (Hirose and Shimamoto 2005), which can strongly affect earthquake energetics and fault slip behaviors. Because the progression of such mechanisms is closely dependent on the amount of heat produced by slip, to understand fault slip behaviors during earthquakes it is crucial to estimate the maximum temperature recorded by the fault rocks.

\footnotetext{
*Correspondence: skaneki@ess.sci.osaka-u.ac.jp

Department of Earth and Space Science, Graduate School of Science, Osaka University, Toyonaka 560-0043, Japan
}

Several temperature proxies have been proposed as indicators of frictional heat recorded by fault rocks (Rowe and Griffith 2015). These include pseudotachylyte formation (e.g., Cowan 1999; Di Toro et al. 2005), mineral transformations (e.g., Hirono et al. 2007; Mishima et al. 2009; Kameda et al. 2011; Evans et al. 2014), thermal decomposition of carbonate minerals (e.g., Han et al. 2007; Oohashi et al. 2014), dehydration and dehydroxylation of clay minerals (e.g., Hirono et al. 2008; Schleicher et al. 2015), and anomalies in fluid-mobile trace element concentrations and strontium isotope ratios (e.g., Ishikawa et al. 2008; Honda et al. 2011). In particular, the thermal maturity of carbonaceous material $(\mathrm{CM})$ has received considerable attention as a new temperature proxy (e.g., Savage et al. 2014; Hirono et al. 2015; Kaneki et al. 2016; Rabinowitz et al. 2017) because the 
organochemical characteristics of CM, including its elemental compositions and molecular structures, change irreversibly with increasing temperature (e.g., Beyssac et al. 2002). The frictional heat recorded by $C M$ in both natural and experimental fault rocks has been investigated by spectroscopic analyses (e.g., Furuichi et al. 2015; Hirono et al. 2015; Kaneki et al. 2016, 2018; Ito et al. 2017; Kouketsu et al. 2017; Kuo et al. 2017) and by determining elemental compositions (Kaneki et al. 2016), biomarker indexes (Polissar et al. 2011; Savage et al. 2014; Sheppard et al. 2015; Rabinowitz et al. 2017), and vitrinite reflectance (e.g., O'Hara 2004; Sakaguchi et al. 2011; Kitamura et al. 2012; Maekawa et al. 2014; Hamada et al. 2015). Several studies have succeeded in inferring slip behaviors on natural faults during past earthquakes from estimations of maximum temperatures recorded by $\mathrm{CM}$ (Savage et al. 2014; Hirono et al. 2015; Kaneki et al. 2016; Mukoyoshi et al. 2018).

Maturation of $\mathrm{CM}$ is accompanied by the release of various volatile organic components (e.g., aliphatics, aromatics), resulting in the formation of a solid residue with extremely high carbon content (e.g., Spokas 2010). This devolatilization process can be strongly affected not only by maximum temperature but also by other factors such as a change in reactivity due to shear damage (mechanochemical effect) and the kinetic effect of the heating rate (e.g., Alexander et al. 1986; Kitamura et al. 2012). Recently, Kaneki et al. (2018) experimentally demonstrated that shear-enhanced mechanochemical effects can promote various organochemical reactions of $\mathrm{CM}$ at relatively low temperature and suggested that maximum temperatures estimated in the previous studies might be overestimated. Although it is known that higher heating rates generally lead to higher pyrolytic temperatures of CM (e.g., Alexander et al. 1986; Schenk et al. 1990; Huang and Otten 1998; Burnham and Braun 1999; Lievens et al. 2013), however, quantitative evaluation of the kinetic effect of heating rate on the CM maturation process during earthquakes remains unknown. Furthermore, several recent estimates of maximum temperatures are based on heating experiments conducted only at slow heating rates of about $1{ }^{\circ} \mathrm{C} \mathrm{s}^{-1}$ (Hirono et al. 2015; Kaneki et al. 2016; Mukoyoshi et al. 2018). For example, Kaneki et al. (2016) inferred maximum temperatures and fault slip distances in the CM-bearing slip zone of an ancient plate-subduction fault developed in Kure Mélange, Shikoku, Japan (Fig. 1), to be $500-600{ }^{\circ} \mathrm{C}$ and $2-9 \mathrm{~m}$, respectively, from the results of heating experiments on host-rock CM conducted using a heating rate of $50{ }^{\circ} \mathrm{C} \mathrm{min}{ }^{-1}$ (approximately $1{ }^{\circ} \mathrm{C} \mathrm{s}^{-1}$ ). This rate is much lower than typical heating rates during earthquake slip (several tens to several hundreds of degrees per second); thus, these estimated temperatures and fault slip behaviors may include uncertainties due to the kinetic effect of heating rate.

In this study, we quantitatively investigated the kinetic effect of heating rate on the thermal maturation of CM by using infrared (IR) and Raman spectrometry and pyrolysis-gas chromatography-mass spectrometry (py-GC/ MS) in conjunction with slow- and fast-heating experiments. On the basis of our results, we show that the effect of heating rate on thermal maturation of $\mathrm{CM}$ has implications for the use of CM maturity as a proxy for frictional heat. We consider information about this effect to be crucial for establishing a more rigorous fault geothermometer and for estimating slip behaviors of past earthquakes.

\section{Materials and methods}

\section{Heating experiments}

To investigate the kinetic effect of heating rate on $\mathrm{CM}$ maturation, we collected CM-bearing bulk-rock samples from non-deformed shale in the Cretaceous Nonokawa Formation, in the Shimanto accretionary complex, which crops out along the coast at Kure, Tosa Town, Japan (Mukoyoshi et al. 2006) (Fig. 1). After extracting pure CM from the bulk samples by chemical treatment ( $\mathrm{HCl}-\mathrm{HF}$ method; see Kaneki et al. 2016 for details), we used a thermogravimetry-differential scanning calorimeter apparatus (STA 449 C Jupiter balance, Netzsch) for our slow-heating experiments. About $30 \mathrm{mg}$ of the $\mathrm{CM}$ was placed in a covered $\mathrm{Pt}_{90} \mathrm{Rh}_{10}$ crucible and heated under $\mathrm{Ar}$ gas flow at a rate of $50{ }^{\circ} \mathrm{C} \mathrm{min}-1$ (approximately $1{ }^{\circ} \mathrm{C} \mathrm{s}^{-1}$ ) from an initial temperature of $50{ }^{\circ} \mathrm{C}$ to target temperatures from 100 to $1000{ }^{\circ} \mathrm{C}$ at $100{ }^{\circ} \mathrm{C}$ intervals.

For the fast-heating experiments, we used a tube furnace to heat each CM sample. About $10 \mathrm{mg}$ of sample was enclosed in a quartz tube (outer diameter, $8 \mathrm{~mm}$; thickness, $1 \mathrm{~mm}$; length, $25 \mathrm{~cm})$ under vacuum $(\leq 10 \mathrm{~Pa})$, and then, the tube was inserted into the tube furnace apparatus, which had been preheated to the target temperature (100$1000{ }^{\circ} \mathrm{C}$ at $100^{\circ} \mathrm{C}$ intervals), for $10 \mathrm{~s}$. We numerically simulated the heating rates during the experiments by adopting a CM particle diameter of $100 \mu \mathrm{m}$ (determined from scanning electron microscope observations) and thermal diffusivities of $1.6 \times 10^{-7}$ and $8.7 \times 10^{-7} \mathrm{~m}^{2} \mathrm{~s}^{-1}$ for $\mathrm{CM}$ and silica glass, respectively (Gustafsson et al. 1979; Turian et al. 1991). Then, we simulated the time-temperature and time-heating rate relationships for a CM particle with these thermophysical properties during the fast-heating experiments (Additional file 1). The simulated temperature profiles indicate that the heating rate increases as the target temperature increases, and the maximum heating rate that can be achieved is $\geq 100^{\circ} \mathrm{C} \mathrm{s}^{-1}$ for all target temperatures except $100{ }^{\circ} \mathrm{C}$ (for which $50{ }^{\circ} \mathrm{C} \mathrm{s}^{-1}$ is the maximum rate) (Additional file 1). Hereafter, therefore, we refer to 
the slow- and fast-heating rates during the heating experiments as 1 and $100{ }^{\circ} \mathrm{C} \mathrm{s}^{-1}$, respectively. We stopped the heating as soon as the targeted temperature was achieved.

\section{Spectroscopic analyses}

To investigate the chemical structures of CM, we conducted IR and Raman spectrometry on powdered CM samples. IR spectra of $\mathrm{CM}$ exhibit various peaks that correspond to organic and inorganic chemical bonds (e.g., Stuart 2004). These include an $\mathrm{O}-\mathrm{H}$ stretching band at around $3400 \mathrm{~cm}^{-1}$; a sharp aromatic $\mathrm{C}-\mathrm{H}$ band at $3050 \mathrm{~cm}^{-1}$; aliphatic hydrocarbon bands at $2960 \mathrm{~cm}^{-1}$ (asymmetrical $\mathrm{CH}_{3}$ stretching), $2930 \mathrm{~cm}^{-1}$ (asymmetrical $\mathrm{CH}_{2}$ stretching), and $2860 \mathrm{~cm}^{-1}$ (symmetrical $\mathrm{CH}_{2}$ stretching); a $\mathrm{C}=\mathrm{O}$ stretching band at $1680 \mathrm{~cm}^{-1}$; an aromatic ring $\mathrm{C}=\mathrm{C}$ stretching band at $1600 \mathrm{~cm}^{-1}$; and weak aliphatic hydrocarbon bending bands at $1455 \mathrm{~cm}^{-1}$ (asymmetrical $\mathrm{CH}_{3}$ bending) and $1375 \mathrm{~cm}^{-1}$ (symmetrical $\mathrm{CH}_{2}$ bending). We followed the methods of Kaneki et al. (2016) to obtain our IR spectra. We used a Fourier transform IR spectrometer (FT/IR-4700, Jasco Inc.) equipped with an IR microscope (IRT-5200, Jasco

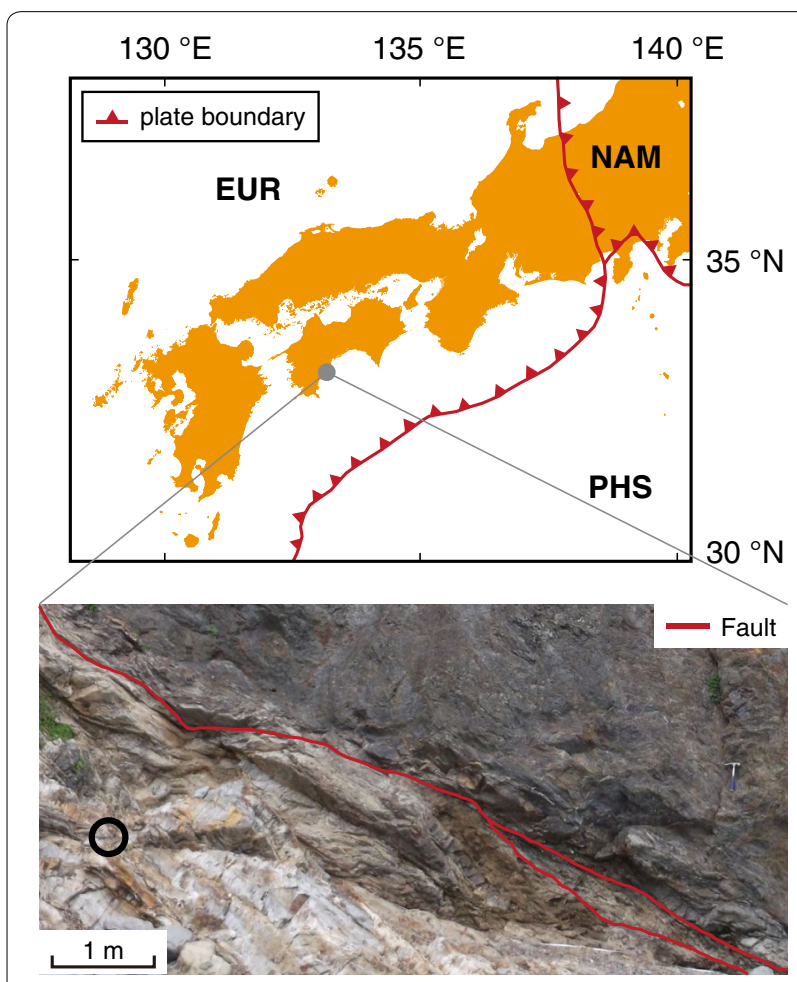

Fig. 1 Example of a CM-bearing fault. Location (upper) and photograph (lower) of an ancient plate-subduction fault developed in the Kure Mélange, Shikoku, Japan. The sampling point of CM-bearing non-deformed shale is shown by the black circle on the photograph of the outcrop. EUR Eurasia plate, NAM North American plate, PHS Philippine Sea plate
Inc.) to obtain IR absorbance spectra of CM retrieved from the shale and from the products of heating at 1 or $100{ }^{\circ} \mathrm{C} \mathrm{s}^{-1}$. The samples were placed on a $\mathrm{CaF}_{2}$ plate and then hand-pressed to prevent saturation of the IR spectra. Before the measurements, plates and samples were dried in an oven at $50{ }^{\circ} \mathrm{C}$ for several hours. To acquire one IR spectrum, 100 spectra were accumulated with a wavenumber resolution of $4 \mathrm{~cm}^{-1}$, a wavenumber range of $4000-1000 \mathrm{~cm}^{-1}$, and an aperture size of $50 \times 50 \mu \mathrm{m}^{2}$. Background intensities of the IR spectra were eliminated by measuring a blank $\mathrm{CaF}_{2}$ plate.

Raman spectra of CM show significant peaks at 13551380 and $1575-1620 \mathrm{~cm}^{-1}$, which are known as disordered (D) and graphite (G) bands, respectively (Tuinstra and Koenig 1970). Several spectral parameters have been used to evaluate the maturity of $\mathrm{CM}$ in metamorphic rocks (e.g., Beyssac et al. 2002; Aoya et al. 2010; Kouketsu et al. 2014; Nakamura et al. 2015) and fault rocks (e.g., Hirono et al. 2015; Kaneki et al. 2016; Kouketsu et al. 2017; Kuo et al. 2017). We followed the methods of Kaneki et al. (2016) to acquire our Raman spectra and spectral parameters. We used a Raman microspectrometer (XploRA, Horiba Jobin-Yvon Inc.) equipped with a laser $(532 \mathrm{~nm})$ to obtain Raman spectra of CM powder derived from the shale and from the samples heated at 1 and $100{ }^{\circ} \mathrm{C} \mathrm{s}^{-1}$. Before the measurements, samples were dried in an oven at $50{ }^{\circ} \mathrm{C}$ for several hours. Although the graphitic structure of $\mathrm{CM}$ has a crystallographic orientation (c-axis orientation), we did not control sample orientation during our spectral measurements because the orientation is unlikely to affect the Raman spectral features (Aoya et al. 2010). We used an exposure time of $10 \mathrm{~s}$ and a laser power of $0.09-0.11 \mathrm{~mW}$ to obtain spectra from the targeted surfaces to avoid thermal damage to the powder samples. Because Raman spectra obtained from the grain boundaries of CM particles might differ from those obtained from the body of CM particles (Tuinstra and Koenig 1970), we adopted a laser spot size of $5 \mu \mathrm{m}$ as sufficiently smaller than the average CM particle size (approximately $100 \mu \mathrm{m}$ ). We then used PeakFit 3.0 software (Systat Software Inc.) to fit the D and G bands to the acquired spectra after a linear baseline correction of $1000-1800 \mathrm{~cm}^{-1}$ (Additional file 2). We determined the intensities of both bands. To compare the spectral features among the acquired Raman spectra, we normalized the spectra so that the height of the strongest peak of each spectrum was the same among the spectra being compared. Ten spectra were obtained from each sample (one spectrum per CM particle), and the mean values and standard deviations of the intensity ratios of the D and G bands $\left(I_{\mathrm{D}} / I_{\mathrm{G}}\right)$ were calculated. All of the calculated $I_{\mathrm{D}} / I_{\mathrm{G}}$ ratios with their standard deviations are summarized in Additional file 3. 

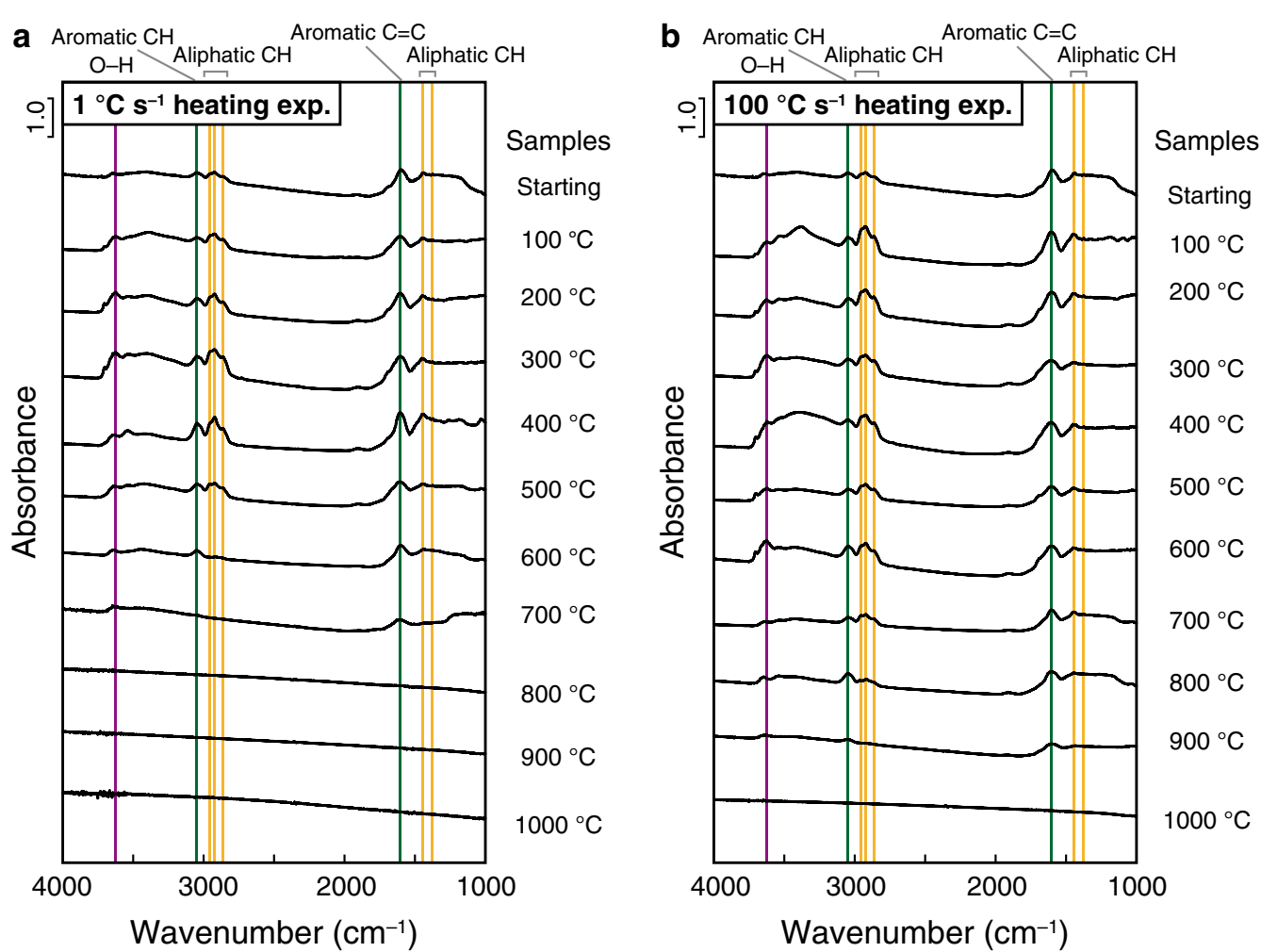

Fig. 2 Representative IR spectra of the analyzed CM. IR spectra of CM from shale and from products heated at a rate of $\mathbf{a} 1{ }^{\circ} \mathrm{C} \mathrm{s}^{-1} \mathrm{or}^{\mathbf{b}} 100^{\circ} \mathrm{C} \mathrm{s}$. exp. experiment

\section{py-GC/MS}

To analyze the composition of gases released from the starting samples and from the samples that had been heated at 1 and $100{ }^{\circ} \mathrm{C} \mathrm{s}^{-1}$, we followed the methods of Kaneki et al. (2016). We used a py-GC/MS system consisting of a model EGA/PY-3030D pyrolyzer (Frontier Lab) and a model GCMS-QP2010 SE GC/MS (Shimadzu) with an UltraALLOY-5 column. About $1 \mathrm{mg}$ of sample was pyrolyzed at $1000^{\circ} \mathrm{C}$ for $1 \mathrm{~min}$ under vacuum $(\leq 2 \mathrm{~Pa})$, and chromatographs and chemical compositions of the released gas were then analyzed. First, the intensities of the chromatographs were normalized by the weight of the analyzed samples, and then, the intensity ratios of toluene to benzene $\left(I_{\text {toluene }} / I_{\text {benzene }}\right)$ were determined. All of the calculated $I_{\text {toluene }} / I_{\text {benzene }}$ ratios are summarized in Additional file 3.

\section{Results}

\section{Spectroscopic characteristics}

The IR spectra of CM from the shale (starting material) showed sharp absorbance peaks for the aliphatic $\mathrm{C}-\mathrm{H}$ (2960, 2930, 2860, 1455, and $\left.1375 \mathrm{~cm}^{-1}\right)$, aromatic $\mathrm{C}-\mathrm{H}$ $\left(3050 \mathrm{~cm}^{-1}\right)$, and $\mathrm{C}=\mathrm{C}$ bonds $\left(1600 \mathrm{~cm}^{-1}\right)$ (Fig. 2). In the spectra of samples heated at $1{ }^{\circ} \mathrm{C} \mathrm{s}^{-1}$, the absorbance peaks of the aliphatic $\mathrm{C}-\mathrm{H}$ bonds and the aromatic
$\mathrm{C}-\mathrm{H}$ bond became weak at $600{ }^{\circ} \mathrm{C}$ and disappeared at $700{ }^{\circ} \mathrm{C}$, and the absorbance peaks of the aromatic $\mathrm{C}=\mathrm{C}$ bond became weak at $700{ }^{\circ} \mathrm{C}$ and disappeared at $800{ }^{\circ} \mathrm{C}$ (Fig. 2a). In the spectra of samples heated at $100{ }^{\circ} \mathrm{C} \mathrm{s}^{-1}$, the absorbance peaks of the aliphatic $\mathrm{C}-\mathrm{H}$ bonds and the aromatic $\mathrm{C}-\mathrm{H}$ bond became weak at $800{ }^{\circ} \mathrm{C}$ and disappeared at 900 and $1000{ }^{\circ} \mathrm{C}$, respectively, and the absorbance peaks of the aromatic $\mathrm{C}=\mathrm{C}$ bond became weak at $900{ }^{\circ} \mathrm{C}$ and disappeared at $1000{ }^{\circ} \mathrm{C}$ (Fig. 2b).

The Raman spectra of all of the analyzed samples showed distinct $D$ and $G$ band peaks, and the intensity of the $\mathrm{D}$ band relative to that of the $\mathrm{G}$ band increased as the target temperature increased (Fig. 3). The $I_{\mathrm{D}} / I_{\mathrm{G}}$ ratios of the samples heated at $1{ }^{\circ} \mathrm{C} \mathrm{s}^{-1}$ increased markedly at $\geq 600{ }^{\circ} \mathrm{C}$, whereas those of samples heated at $100{ }^{\circ} \mathrm{C} \mathrm{s}^{-1}$ started to increase at $\geq 900{ }^{\circ} \mathrm{C}$ (Fig. 4).

\section{py-GC/MS}

Chromatographs for the CM sample from shale and for the products of the heating experiments included clear peaks of various aromatic compounds, and the samples were especially rich in benzene and toluene (Fig. 5). The chromatographs for the products of the heating experiments showed a systematic decrease in peak intensities as the target temperature increased. Intensities of 


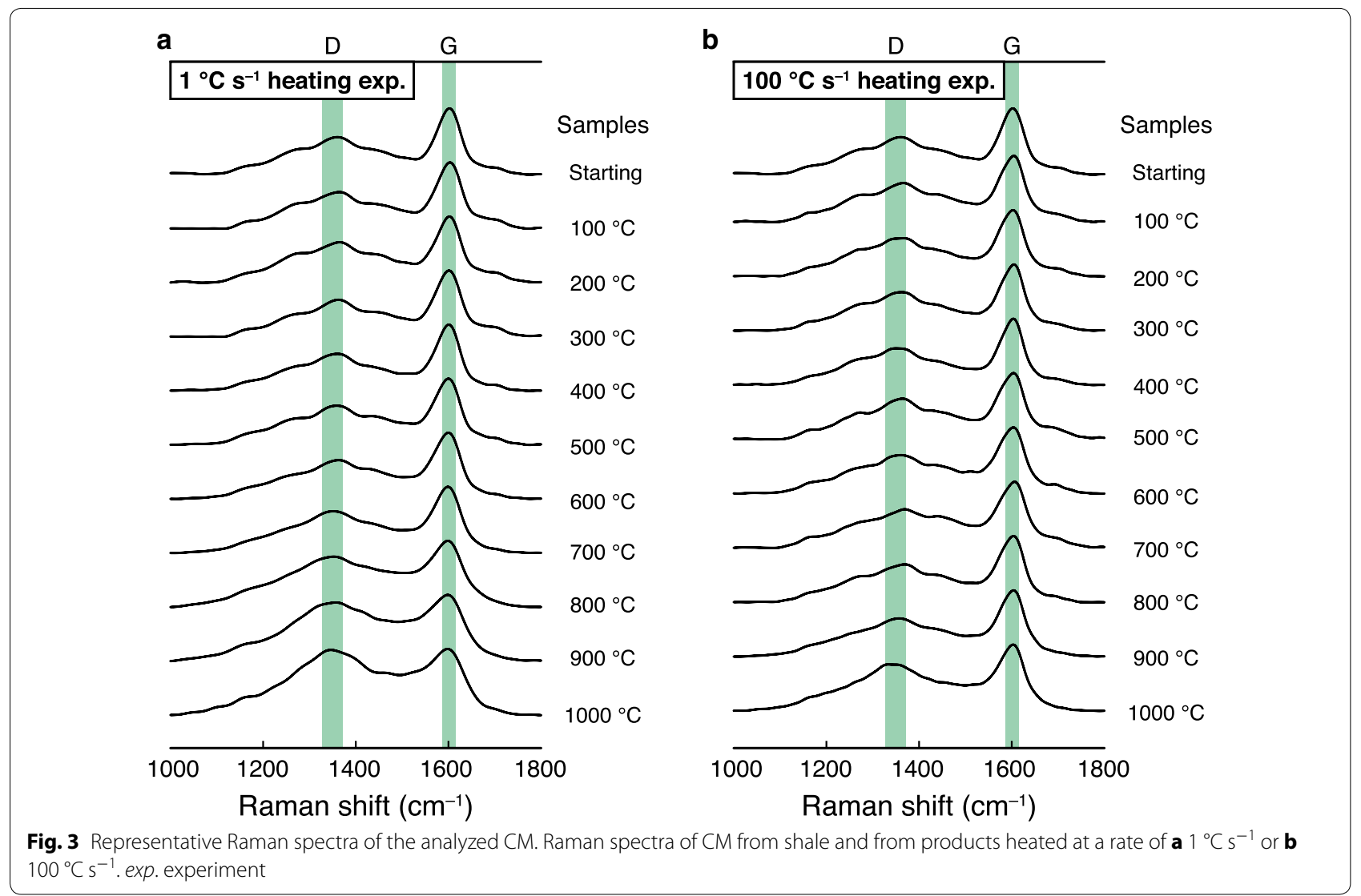

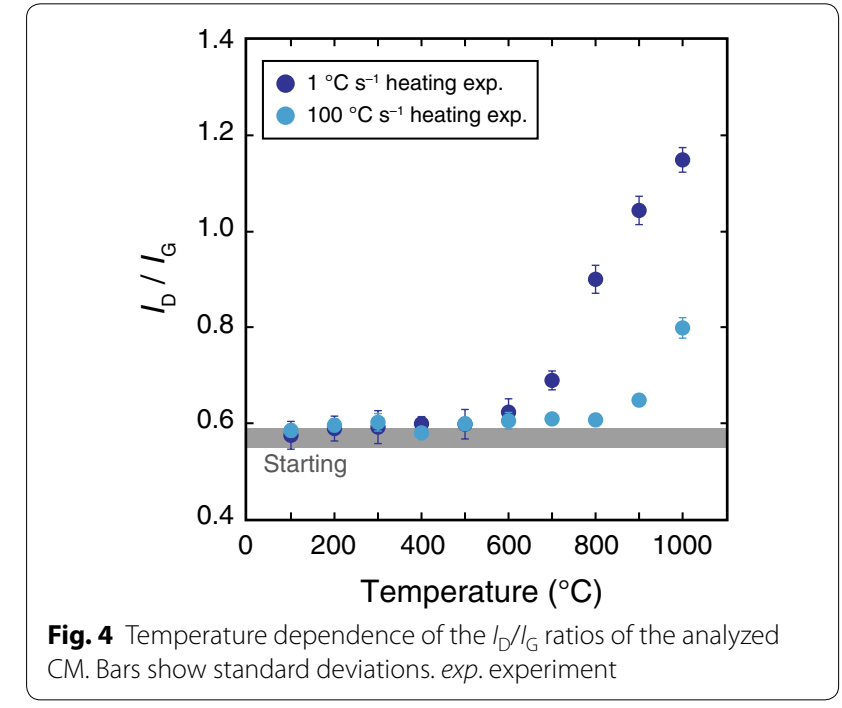

the benzene and toluene peaks of $\mathrm{CM}$ sample heated at $1{ }^{\circ} \mathrm{C} \mathrm{s}^{-1}$ decreased markedly at $500{ }^{\circ} \mathrm{C}$ and approached zero at $700{ }^{\circ} \mathrm{C}$ (benzene) and $600{ }^{\circ} \mathrm{C}$ (toluene). In contrast, for the $\mathrm{CM}$ sample heated at $100{ }^{\circ} \mathrm{C} \mathrm{s}^{-1}$, chromatograph peak intensities started to decrease at $800{ }^{\circ} \mathrm{C}$ and approached zero at $1000{ }^{\circ} \mathrm{C}$. The $I_{\text {toluene }} / I_{\text {benzene }}$ ratios of the $\mathrm{CM}$ sample heated at $1{ }^{\circ} \mathrm{C} \mathrm{s}^{-1}$ started to decrease at $500{ }^{\circ} \mathrm{C}$, whereas the ratios of samples heated at $100{ }^{\circ} \mathrm{C} \mathrm{s}^{-1}$ showed a sudden decrease above $800{ }^{\circ} \mathrm{C}$. The $I_{\text {toluene }} / I_{\text {benzene }}$ ratios in samples heated at $1{ }^{\circ} \mathrm{C} \mathrm{s}^{-1}$ to $\geq 700{ }^{\circ} \mathrm{C}$ and in those heated at $100{ }^{\circ} \mathrm{C} \mathrm{s}^{-1}$ to $1000{ }^{\circ} \mathrm{C}$ could not be determined because of the extinction of the toluene and benzene peaks on those chromatographs.

\section{Discussion and conclusions}

The py-GC/MS chromatographs revealed that the dominant components of the analyzed $\mathrm{CM}$ samples were benzene and toluene, and the amounts of these compounds decreased as the target temperature increased (Fig. 5). The presence of toluene or phenol, which have aliphatic $\mathrm{C}-\mathrm{H}$ or $\mathrm{O}-\mathrm{H}$ bonds in their molecular structures, clearly indicates that the $\mathrm{CM}$ from shale was not derived from $\mathrm{C}-\mathrm{H}-\mathrm{O}$-rich fluid at high temperature $\left(\geq 500{ }^{\circ} \mathrm{C}\right.$ ) because such depositional CM is almost fully graphitized (e.g., Luque et al. 2009). In samples heated at 1 and $100{ }^{\circ} \mathrm{C} \mathrm{s}^{-1}$, the chromatographic peak of toluene disappeared (Fig. 5), and extinction of the aliphatic $\mathrm{C}-\mathrm{H}$ absorbance peaks was observed on the IR spectra (Fig. 2), at 600 and $900^{\circ} \mathrm{C}$, respectively. This result clearly 


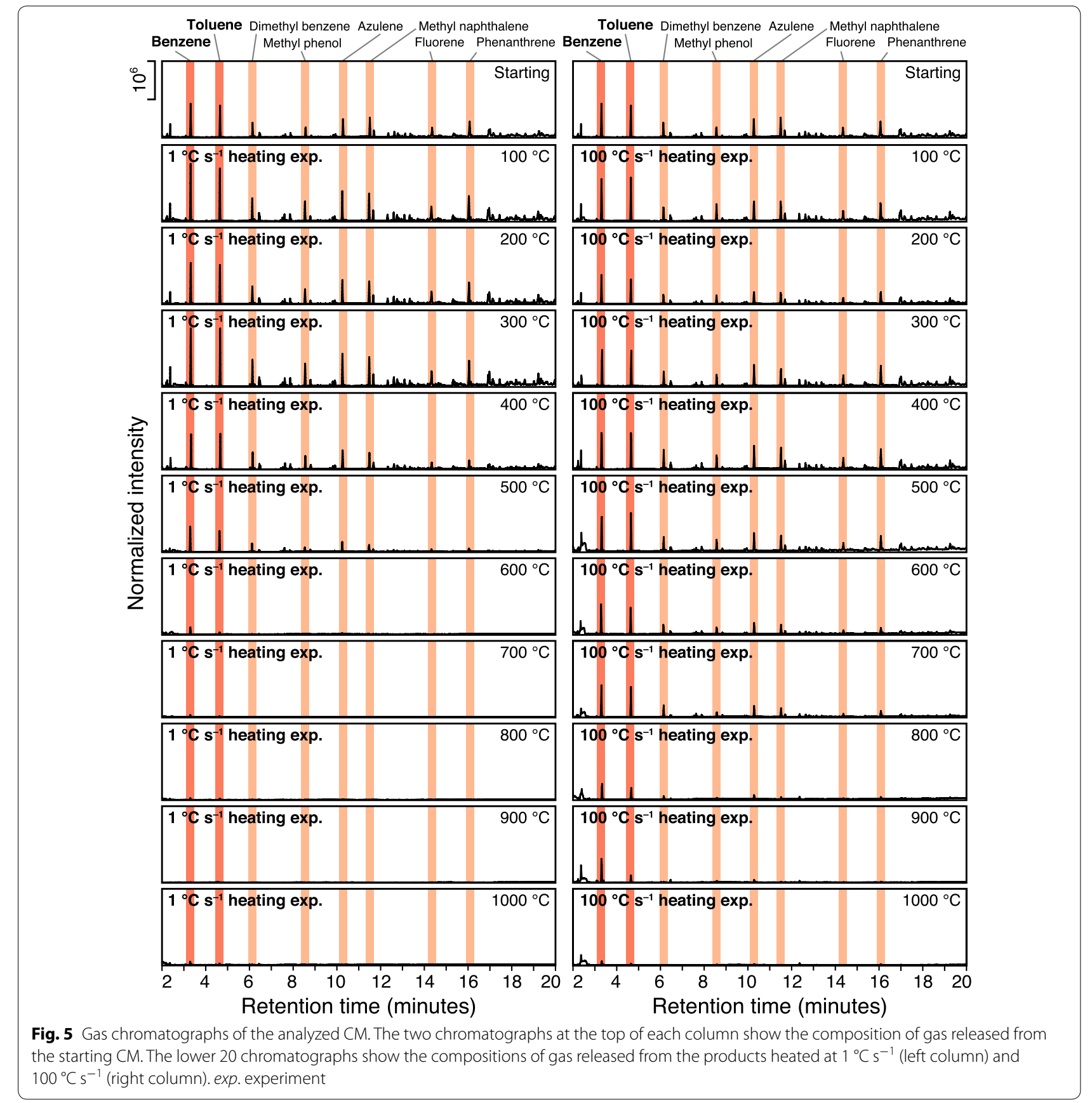

Toluene Dimethyl benzene Azulene Methyl naphthalene

indicates that toluene dominantly controlled the amount of aliphatic $\mathrm{C}-\mathrm{H}$ chain in the samples. Furthermore, the almost simultaneous disappearance of the chromatographic peak for benzene and the absorbance peak of the aromatic $\mathrm{C}=\mathrm{C}$ bond at $700-800$ and $1000{ }^{\circ} \mathrm{C}$ in the samples heated at 1 and $100{ }^{\circ} \mathrm{C} \mathrm{s}^{-1}$, respectively (Figs. 2, 5 ), suggests that benzene was the main contributor to the aromatic $\mathrm{C}=\mathrm{C}$ absorbance peaks on the IR spectra. The $I_{\mathrm{D}} / I_{\mathrm{G}}$ ratios of the Raman spectra for the products heated at 1 and $100{ }^{\circ} \mathrm{C} \mathrm{s}^{-1}$ began to increase at $\geq 600$ and $\geq 900{ }^{\circ} \mathrm{C}$, respectively (Fig. 4). This result is well consistent with the findings of several prior studies that showed $I_{\mathrm{D}} / I_{\mathrm{G}}$ ratios increased when intact $\mathrm{CM}$ was exposed to high temperatures of several hundreds of degrees Celsius by heating or friction experiments (e.g., Furuichi et al. 2015; Hirono et al. 2015; Kaneki et al. 2016, 2018; Ito et al. 2017). In these temperature ranges, no significant change in the molecular compounds in gases released from the heating products was observed except for a small decrease in the chromatographic peak of 


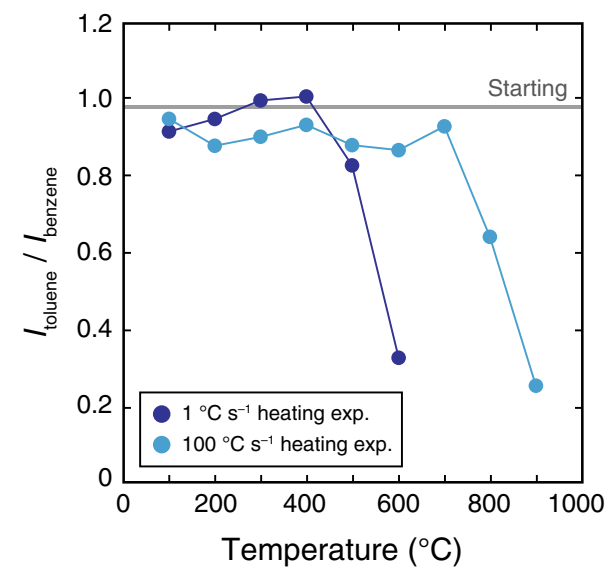

Fig. 6 Temperature dependence of the $I_{\text {toluene }} / I_{\text {benzene }}$ ratios of the analyzed $\mathrm{CM}$. The ratios of the products heated to $\geq 700^{\circ} \mathrm{C}$ at $1{ }^{\circ} \mathrm{C} \mathrm{s}^{-1}$ and to $1000{ }^{\circ} \mathrm{C}$ at $100{ }^{\circ} \mathrm{C} \mathrm{s}^{-1}$ are not available owing to extinction of the toluene and benzene peaks. exp. experiment

benzene (Fig. 5). This result suggests that the changes in the $I_{\mathrm{D}} / I_{\mathrm{G}}$ ratios are possibly attributable to pyrolysis of residual benzene with relatively strong bonds within the graphitic sheets accompanied by the formation of a disordered structure as a result of pyrolytic rearrangement. The abrupt decreases in the $I_{\text {toluene }} / I_{\text {benzene }}$ ratios at $\geq 500$ and $\geq 800{ }^{\circ} \mathrm{C}$ in the products heated at 1 and $100{ }^{\circ} \mathrm{C} \mathrm{s}^{-1}$, respectively, might be due to the difference in the pyrolytic temperatures of benzene and toluene (Fig. 6).

On the basis of these results, we inferred that the dominant maturation process controlling the changes in the organochemical characteristics of the starting CM during the heating experiments was the thermal decomposition of benzene and toluene, which resulted in the extinction of absorbance peaks in the IR spectra at higher temperatures, and the subsequent rearrangement of residual aromatic nuclei, which in turn increased the $I_{\mathrm{D}} / I_{\mathrm{G}}$ ratios of the Raman spectra. Although Kaneki et al. (2016) attributed changes in the characteristics of IR and Raman spectra of heated CM to the thermal decomposition of toluene and the growth of aromatic rings, our series of organochemical analyses, including py-GC/MS analyses, revealed that thermal decomposition not only of toluene but also of benzene, along with subsequent structural rearrangement that increased the $I_{\mathrm{D}} / I_{\mathrm{G}}$ ratios, may have played a significant role in maturation process of our $\mathrm{CM}$ at high temperature.

Although our CM heating experiments were conducted under dry conditions, the in situ environment of natural fault rocks is usually water-saturated. Water saturation may affect the CM maturation process by providing an exogenous source of hydrogen (e.g., Lewan 1997). However, this hydrothermal effect is reported to appear only after a long reaction time of $\geq 70 \mathrm{~h}$ at temperatures of $\geq 330{ }^{\circ} \mathrm{C}$ (Lewan 1997). Because our heating experiments were completed within $20 \mathrm{~min}$, we can ignore the effect of water saturation.

The $I_{\mathrm{D}} / I_{\mathrm{G}}$ ratio of Raman spectra has long been believed to decrease with increasing CM maturity (e.g., Beyssac et al. 2002; Kuo et al. 2017), whereas we observed a completely opposite trend in our results (Fig. 4). However, recent friction and heating experiments conducted with pure $\mathrm{CM}$ or $\mathrm{CM}$-bearing samples have demonstrated increases in the $I_{\mathrm{D}} / I_{\mathrm{G}}$ ratios of CM with increasing temperature (e.g., Furuichi et al. 2015; Hirono et al. 2015; Kaneki et al. 2016, 2018; Ito et al. 2017). Furthermore, Mukoyoshi et al. (2018) reported an increase in the $I_{\mathrm{D}} / I_{\mathrm{G}}$ ratios of $\mathrm{CM}$ in a natural pseudotachylyte-bearing slip zone relative to the ratios in host-rock samples. These contradictory results might be explained by heterogeneity of the initial condition of the CMs among these studies. For example, Kuo et al. (2017) obtained lower $I_{\mathrm{D}} / I_{\mathrm{G}}$ ratios for anthracite samples in a high-velocity friction experiment, whereas Furuichi et al. (2015) reported an increase in the $I_{\mathrm{D}} / I_{\mathrm{G}}$ ratios of brown coal in a similar friction experiment. If it is assumed that the direction of change in the $I_{\mathrm{D}} / I_{\mathrm{G}}$ ratios of Raman spectra with increasing temperature depends on the initial maturity of the starting CM (e.g., Kouketsu et al. 2014, 2017; Schito et al. 2017), the increasing $I_{\mathrm{D}} / I_{\mathrm{G}}$ ratios of the Raman spectra of CM with increasing temperature in our study might be attributable to the relatively low maturity of the starting $\mathrm{CM}$ (bituminous coal). Thus, to characterize fully the temperature-maturity relationship, further friction and heating experiments and organochemical analyses should be performed using $\mathrm{CM}$ samples with various initial maturities.

We obtained experimental evidence for the first time that a kinetic effect of heating rate is involved in various organochemical reactions of $\mathrm{CM}$. The results of our organochemical analyses clearly indicate that a higher heating rate can inhibit various $\mathrm{CM}$ maturation reactions, including the thermal decomposition of several aromatic compounds and structural rearrangement, thus causing extinction of some IR spectral absorbance peaks, increases in the $I_{\mathrm{D}} / I_{\mathrm{G}}$ ratios of Raman spectra, and decreases in the $I_{\text {toluene }} / I_{\text {benzene }}$ ratios on py-GC/MS chromatographs (Fig. 7). These results suggest that the maximum temperatures reported previously (Hirono et al. 2015; Kaneki et al. 2016; Mukoyoshi et al. 2018) might be too low. On the other hand, Kaneki et al. (2018) demonstrated that shear-induced mechanochemical effects can increase a reactivity of various organochemical reactions, thus lowering the temperatures necessary for the occurrence of $\mathrm{CM}$ maturation reactions by approximately $100{ }^{\circ} \mathrm{C}$ under a normal stress of $3 \mathrm{MPa}$ and a slip distance of $10 \mathrm{~m}$ (Fig. 7). Although this study focused only on the kinetic effect of heating rate, to understand the CM maturation process during earthquake slip and to establish a more rigorous fault geothermometer based on $\mathrm{CM}$ 

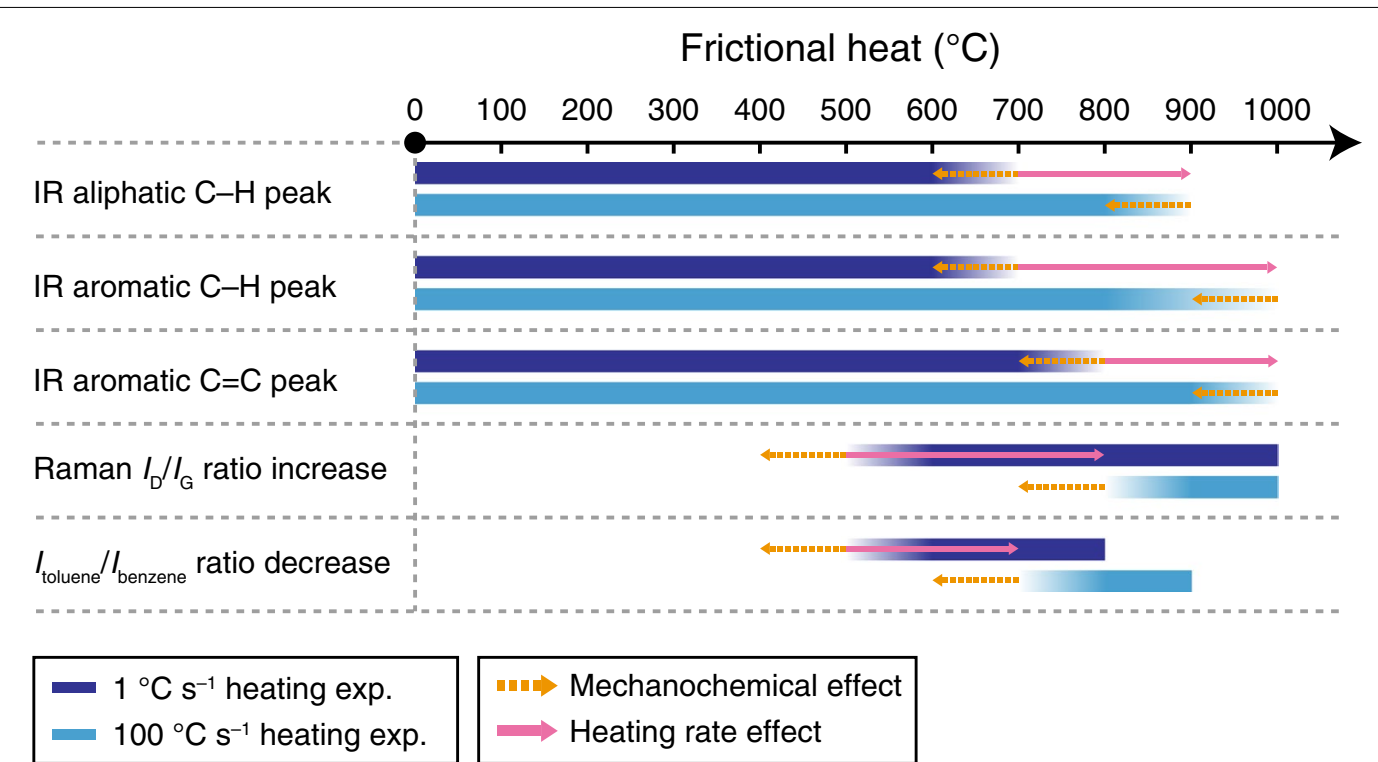

Fig. 7 Summary of organochemical reactions of CM as a function of temperature. Quantitative data on the mechanochemical effect on reaction temperature are from Kaneki et al. (2018), who reported that the mechanochemical effect can cause CM maturation reactions to occur at temperatures approximately $100^{\circ} \mathrm{C}$ lower under a normal stress of $3 \mathrm{MPa}$ and a slip distance of $10 \mathrm{~m}$. exp. experiment

maturity, these two, possibly opposite, effects should be considered simultaneously.

In this study, we focused on how the heating rate might affect the maturation of CM during earthquake slip, and demonstrated experimentally that a high heating rate can inhibit various organochemical reactions of CM. Our results suggest that the maximum slip zone temperatures estimated previously by slow-rate CM heating experiments (Hirono et al. 2015; Kaneki et al. 2016; Mukoyoshi et al. 2018) might be underestimated. Furthermore, mechanochemical effects during earthquake slip can also strongly affect the maturation of CM (Kaneki et al. 2018). Therefore, comprehensive consideration of the effects on CM maturation of both heating rate and mechanochemistry, as well as of the initial maturity of the starting $\mathrm{CM}$, is needed to establish a more rigorous proxy of frictional heat recorded in fault rocks and to infer fault slip behaviors during earthquakes.

\section{Additional files}

Additional file 1. Numerical simulation results for the heating experiments. Description of data: Simulated experimental relationships between $\mathbf{a}$ temperature and $\mathbf{b}$ heating rate and time for a $100-\mu \mathrm{m}$-diameter particle of $\mathrm{CM}$.

Additional file 2. Peak decomposition method for Raman spectra. Description of data: Representative Raman spectrum $\left(800^{\circ} \mathrm{C}\right.$, fast-rate heating experiment) with peaks decomposed for calculation of the $I_{D} / I_{G}$ ratio. Our $I_{D} / I_{G}$ ratios roughly correspond to $I_{D 1} / I_{D 2}$ ratios calculated by several prior studies (e.g., Furuichi et al. 2015; Ito et al. 2017).

Additional file 3. Estimated Raman spectral parameters and gas composition ratios. Description of data: Average $I_{D} / I_{G}$ ratios with standard deviations and $I_{\text {toluene }} / I_{\text {benzene }}$ ratios, for the starting CM and the products of heating experiments.

\section{Abbreviations}

CM: carbonaceous material; EUR: Eurasia plate; $I_{D} / I_{G}$ : intensity ratio of the $D$ and $\mathrm{G}$ bands of Raman spectra; IR: infrared; $I_{\text {toluene }} / \mathrm{I}_{\text {benzene }}$ : intensity ratio of the benzene and toluene peaks on gas chromatographs; NAM: North American plate; PHS: Philippine Sea plate; py-GC/MS: pyrolysis-gas chromatographymass spectrometry.

\section{Authors' contributions}

Both authors designed the study. SK carried out all of the experiments, analyses, and numerical simulations. Both authors contributed to the interpretation of the results, collaborated in writing the early drafts. Both authors read and approved the final manuscript.

\section{Acknowledgements}

The authors thank Tadashi Kondo for help with our heating experiments. We are also grateful to Takuji Yamada for editing this paper and to Patrick Fulton and an anonymous reviewer for giving many constructive comments.

\section{Competing interests}

The authors declare that they have no competing interests.

\section{Availability of data and materials}

All data used in this study are available in the figures, additional files, and references. The data are also available from the corresponding author upon request.

\section{Consent for publication}

Not applicable.

\section{Ethics approval and consent to participate} Not applicable.

\section{Funding}

SK was supported by a Grant-in-Aid for Japan Society for the Promotion of Science (JSPS) Fellows (KAKENHI No. 17J01607), and TH was supported by a Grant-in-Aid for Scientific Research (B) (KAKENHI No. 15H03737) from JSPS and by Grants-in-Aid for Scientific Research on Innovative Areas (Crustal Dynamics, KAKENHI No. 26109004) from the Ministry of Education, Culture, Sports, Science and Technology of Japan. 


\section{Publisher's Note}

Springer Nature remains neutral with regard to jurisdictional claims in published maps and institutional affiliations.

Received: 31 March 2018 Accepted: 23 May 2018

Published online: 04 June 2018

\section{References}

Alexander R, Strachan MG, Kagi Rl, van Bronswijk W (1986) Heating rate effects on aromatic maturity indicators. Org Geochem 10:997-1003. https://doi. org/10.1016/S0146-6380(86)80038-9

Aoya M, Kouketsu Y, Endo S, Shimizu H, Mizukami T, Nakamura D, Wallis S (2010) Extending the applicability of the Raman carbonaceous-material geothermometer using data from contact metamorphic rocks. J Metamorph Geol 28:895-914. https://doi.org/10.1111/j.1525-1314.2010.00896 $x$

Beyssac O, Goffé B, Chopin C, Rouzaud JN (2002) Raman spectra of carbonaceous material in metasediments: a new geothermometer. J Metamorphic Geol 20:859-871. https://doi.org/10.1046/j.1525-1314.2002.00408.x

Burnham AK, Braun RL (1999) Global kinetic analysis of complex materials. Energy Fuels 13:1-22. https://doi.org/10.1021/ef9800765

Chester JS, Chester FM, Kronenberg AK (2005) Fracture surface energy of the Punchbowl fault, San Andreas system. Nature 437:133-136. https://doi. org/10.1038/nature03942

Cowan DS (1999) Do faults preserve a record of seismic slip? A field geologist's opinion. J Struct Geol 21:995-1001. https://doi.org/10.1016/S0191 -8141(99)00046-2

Di Toro G, Nielsen S, Pennacchioni G (2005) Earthquake rupture dynamics frozen in exhumed ancient faults. Nature 436:1009-1012. https://doi. org/10.1038/nature03910

Evans JP, Prante MR, Janecke SU, Ault AK, Newell DL (2014) Hot faults: iridescent slip surfaces with metallic luster document high-temperature ancient seismicity in the Wasatch fault zone, Utah, USA. Geology 42:623-626. https://doi.org/10.1130/G35617.1

Furuichi H, Ujiie K, Kouketsu Y, Saito T, Tsutsumi A, Wallis S (2015) Vitrinite reflectance and Raman spectra of carbonaceous material as indicators of frictional heating on faults: constraints from friction experiments. Earth Planet Sci Lett 424:191-200. https://doi.org/10.1016/j.epsl.2015.05.037

Gustafsson SE, Karawacki E, Khan MN (1979) Transient hot-strip method for simultaneously measuring thermal conductivity and thermal diffusivity of solids and fluids. J Phys D Appl Phys 12:1411-1421

Hamada Y, Sakaguchi A, Tanikawa W, Yamaguchi A, Kameda J, Kimura G (2015) Estimation of slip rate and fault displacement during shallow earthquake rupture in the Nankai subduction zone. Earth Planets Space 67:39. https ://doi.org/10.1186/s40623-015-0208-0

Han R, Shimamoto T, Hirose T, Ree JH, Ando J (2007) Ultralow friction of carbonate faults caused by thermal decomposition. Science 316:878-881. https://doi.org/10.1126/science.1139763

Hirono T, Yokoyama T, Hamada Y, Tanikawa W, Mishima T, Ikehara M, Famin V, Tanimizu M, Lin W, Soh W, Song SR (2007) A chemical kinetic approach to estimate dynamic shear stress during the 1999 Taiwan Chi-Chi earthquake. Geophys Res Lett 34:L19308. https://doi.org/10.1029/2007G L030743

Hirono T, Fujimoto K, Yokoyama T, Hamada Y, Tanikawa W, Tadai O, Mishima T, Tanimizu M, Lin W, Soh W, Song SR (2008) Clay mineral reactions caused by frictional heating during an earthquake: an example from the Taiwan Chelungpu fault. Geophys Res Lett 35:L16303. https://doi. org/10.1029/2008GL034476

Hirono T, Maekawa Y, Yabuta H (2015) Investigation of the records of earthquake slip in carbonaceous materials from the Taiwan Chelungpu fault by means of infrared and Raman spectroscopies. Geochem Geophys Geosyst 16:1233-1253. https://doi.org/10.1002/2014GC005622

Hirose T, Shimamoto T (2005) Growth of molten zone as a mechanism of slip weakening of simulated faults in gabbro during frictional melting. J Geophys Res 110:B05202. https://doi.org/10.1029/2004JB003207

Honda G, Ishikawa T, Hirono T, Mukoyoshi H (2011) Geochemical signals for determining the slip-weakening mechanism of an ancient megasplay fault in the Shimanto accretionary complex. Geophys Res Lett 38:L06310. https://doi.org/10.1029/2011GL046722

Huang WL, Otten GA (1998) Oil generation kinetics determined by DAC-FS/IR pyrolysis: technique development and preliminary results. Org Geochem 5-7:1119-1137. https://doi.org/10.1016/S0146-6380(98)00099-0

Ishikawa T, Tanimizu M, Nagaishi K, Matsuoka J, Tadai O, Sakaguchi M, Hirono T, Mishima T, Tanikawa W, Lin W, Kikuta H, Soh W, Song S (2008) Coseismic fluid-rock interactions at high temperatures in the Chelungpu fault. Nat Geosci 1:679-683. https://doi.org/10.1038/ngeo308

Ito K, Ujiie K, Kagi H (2017) Detection of increased heating and estimation of coseismic shear stress from Raman spectra of carbonaceous material in pseudotachylytes. Geophys Res Lett 44:1749-1757. https://doi. org/10.1002/2016GL072457

Kameda J, Ujiie K, Yamaguchi A, Kimura G (2011) Smectite to chlorite conversion by frictional heating along a subduction thrust. Earth Planet Sci Lett 305:161-170. https://doi.org/10.1016/j.epsl.2011.02.051

Kaneki S, Hirono T, Mukoyoshi H, Sampei Y, Ikehara M (2016) Organochemical characteristics of carbonaceous materials as indicators of heat recorded on an ancient plate-subduction fault. Geochem Geophys Geosyst 17:2855-2868. https://doi.org/10.1002/2016GC006368

Kaneki S, Ichiba T, Hirono T (2018) Mechanochemical effect on maturation of carbonaceous material: implications for thermal maturity as a proxy for temperature in estimation of coseismic slip parameters. Geophys Res Lett 45:2248-2256. https://doi.org/10.1002/2017GL076791

Kitamura M, Mukoyoshi H, Fulton PM, Hirose T (2012) Coal maturation by frictional heat during rapid fault slip. Geophys Res Lett 39:L16302. https:// doi.org/10.1029/2012GL052316

Kouketsu Y, Mizukami T, Mori H, Endo S, Aoya M, Hara H, Nakamura D, Wallis S (2014) A new approach to develop the Raman carbonaceous material geothermometer for low-grade metamorphism using peak width. Island Arc 23:33-50. https://doi.org/10.1111/iar.12057

Kouketsu Y, Shimizu I, Wang Y, Yao L, Ma S, Shimamoto T (2017) Raman spectra of carbonaceous materials in a fault zone in the Longmenshan thrust belt, China; comparisons with those of sedimentary and metamorphic rocks. Tectonophysics 699:129-145. https://doi.org/10.1016/j.tecto 2017.01.015

Kuo LW, Felice FD, Spagnuolo E, Di Toro G, Song SR, Aretusini S, Li H, Suppe J, Si J, Wen CY (2017) Fault gouge graphitization as evidence of past seismic slip. Geology. https://doi.org/10.1130/G39295.1

Lewan MD (1997) Experiments on the role of water in petroleum formation. Geochem Cosmochem Acta 61:3691-3723. https://doi.org/10.1016/ S0016-7037(97)00176-2

Lievens C, Ci D, Bai Y, Ma L, Zhang R, Chen JY, Gai Q, Long Y, Guo X (2013) A study of slow pyrolysis of one low rank coal via pyrolysis-GC/MS. Fuel Process Technol 116:85-93. https://doi.org/10.1016/j.fuproc.2013.04.026

Luque FJ, Ortega L, Barrenechea JF, Millward D, Beyssac O, Huizenga JM (2009) Deposition of highly crystalline graphite from moderate-temperature fluids. Geology 37:275-278. https://doi.org/10.1130/G25284A.1

Maekawa Y, Hirono T, Yabuta H, Mukoyoshi H, Kitamura M, Ikehara M, Tanikawa W, Ishikawa T (2014) Estimation of slip parameters associated with frictional heating during the 1999 Taiwan Chi-Chi earthquake by vitrinite reflectance geothermometry. Earth Planets Space 66:28. https://doi. org/10.1186/1880-5981-66-28

Mishima T, Hirono T, Nakamura N, Tanikawa W, Soh W, Song S (2009) Changes to magnetic minerals caused by frictional heating during the 1999 Taiwan Chi-Chi earthquake. Earth Planets Space 61:797-801. https://doi. org/10.1186/BF03353185

Mukoyoshi H, Sakaguchi A, Otsuki K, Hirono T, Soh W (2006) Co-seismic frictional melting along an out-of-sequence thrust in the Shimanto accretionary complex. Implications on the tsunamigenic potential of splay faults in modern subduction zones. Earth Planet Sci Lett 245:330-343. https://doi.org/10.1016/j.epsl.2006.02.039

Mukoyoshi H, Kaneki S, Hirono T (2018) Slip parameters on major thrusts at a convergent plate boundary: regional heterogeneity of potential slip distance at the shallow portion of the subducting plate. Earth Planets Space 70:36. https://doi.org/10.1186/s40623-018-0810-z

Nakamura Y, Oohashi K, Toyoshima T, Satish-Kumar M, Akai J (2015) Straininduced amorphization of graphite in fault zones of the Hidaka metamorphic belt, Hokkaido, Japan. J Struct Geol 72:142-161. https://doi. org/10.1016/j.jsg.2014.10.012 
O'Hara K (2004) Paleo-stress estimates on ancient seismogenic faults based on frictional heating of coal. Geophys Res Lett 31:L03601. https://doi. org/10.1029/2003GL018890

Oohashi K, Han R, Hirose T, Shimamoto T, Omura K, Matsuda T (2014) Carbonforming reactions under a reducing atmosphere during seismic fault slip. Geology 42:787-790. https://doi.org/10.1130/G35703.1

Polissar PJ, Savage HM, Broadsky EE (2011) Extractable organic material in fault zones as a tool to investigate frictional stress. Earth Planet Sci Lett 311:439-447. https://doi.org/10.1016/j.epsl.2011.09.004

Rabinowitz HS, Polissar PJ, Savage HM (2017) Reaction kinetics of alkenone and n-alkane thermal alteration at seismic timescales. Geochem Geophys Geosyst 18:204-219. https://doi.org/10.1002/2016GC006553

Rowe C, Griffith WA (2015) Do faults preserve a record of seismic slip: a second opinion. J Struct Geol 78:1-26. https://doi.org/10.1016/j.jsg.2015.06.006

Sakaguchi A, Chester F, Curewitz D, Fabbri O, Goldsby D, Kimura G, Li CF, Masaki Y, Screaton EJ, Tsutsumi A, Ujiie K, Yamaguchi A (2011) Seismic slip propagation to the updip end of plate boundary subduction interface faults: vitrinite reflectance geothermometry on Integrated Ocean Drilling Program NanTroSEIZE cores. Geology 39:395-398. https://doi. org/10.1130/G31642.1

Savage HM, Polissar PJ, Sheppard R, Rowe CD, Broadsky EE (2014) Biomarkers heat up during earthquakes: new evidence of seismic slip in the rock record. Geology 42:99-102. https://doi.org/10.1130/G34901.1

Schenk HJ, Witte EG, Littke R, Schwochau K (1990) Structural modifications of vitrinite and alginite concentrates during pyrolytic maturation at different heating rates. A combined infrared, 13C NMR and microscopical study. Org Geochem 16:943-950. https://doi.org/10.1016/0146-6380(90)90130-R
Schito A, Romano C, Corrado S, Grigo D, Poe B (2017) Diagenetic thermal evolution of organic matter by Raman spectroscopy. Org Geochem 106:57-67. https://doi.org/10.1016/j.orggeochem.2016.12.006

Schleicher AM, Boles A, van der Pluijm BA (2015) Response of natural smectite to seismogenic heating and potential implications for the 2011 Tohoku earthquake in the Japan Trench. Geology 43:755-758. https://doi. org/10.1130/G36846.1

Sheppard RE, Polissar PJ, Savage HM (2015) Organic thermal maturity as a proxy for frictional fault heating: experimental constraints on methylphenanthrene kinetics at earthquake timescales. Geochim Cosmochim Acta 151:103-116. https://doi.org/10.1016/j.gca.2014.11.020

Sibson RH (1973) Interactions between temperature and pore-fluid pressure during earthquake faulting and a mechanism for partial or total stress relief. Nature 243:66-68. https://doi.org/10.1038/physci243066a0

Spokas KA (2010) Review of the stability of biochar in soils: predictability of O: C molar ratios. Carbon Manag 1:289-303. https://doi.org/10.4155/ cmt.10.32

Stuart B (2004) Infrared spectrometry: fundamentals and applications. Wiley, Chichester, p 244

Tuinstra F, Koenig JL (1970) Raman spectrum of graphite. J Chem Phys 53:1126-1130. https://doi.org/10.1063/1.1674108

Turian RM, Sung DJ, Hsu FL (1991) Thermal conductivity of granular coals, coalwater mixtures and multi-solid/liquid suspensions. Fuel 70:1157-1172. https://doi.org/10.1016/0016-2361(91)90237-5

\section{Submit your manuscript to a SpringerOpen ${ }^{\circ}$ journal and benefit from:}

- Convenient online submission

- Rigorous peer review

- Open access: articles freely available online

- High visibility within the field

- Retaining the copyright to your article

Submit your next manuscript at $\boldsymbol{\nabla}$ springeropen.com 